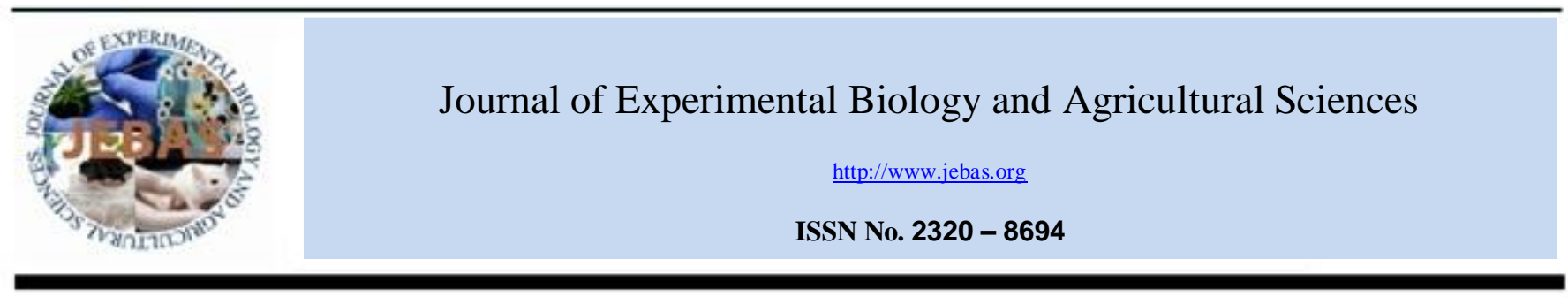

\title{
DETERMINANTS OF SOYBEAN [Glycine max (L.) Merrill] PRODUCTION SYSTEM IN BENIN
}

\section{Charlotte Carmelle Zoundji ${ }^{1}$, Pascal Houngnandan ${ }^{1, *}$, Houinsou Dedehouanou ${ }^{2}$ and Fatiou Toukourou $^{3}$}

\footnotetext{
${ }^{1}$ Laboratoire de Microbiologie des Sols et d'Ecologie Microbienne (LMSEM), Faculté des Sciences Agronomiques, Université d'Abomey-Calavi, 01 BP 526 Recette Principale, Cotonou/Bénin.

${ }^{2}$ Laboratoire d'Economie Rurale et de Gestion des Exploitations Agricoles (LERGEA), Faculté des Sciences Agronomiques, Université d'Abomey-Calavi, 01 BP 526 Recette Principale, Cotonou/Benin

${ }^{3}$ Laboratoire de Microbiologie et de Technologie Alimentaire, Faculté des Sciences et Techniques, Université d'Abomey-Calavi 01 BP 526 Cotonou
}

Received - August 06, 2015; Revision - September 01, 2015; Accepted - October 07, 2015

Available Online - October 20, 2015

DOI: http://dx.doi.org/10.18006/2015.3(5).430.439

KEYWORDS
Soybean
Cropping practices
Yield level
Determinants
Benin

\begin{abstract}
Present study was conducted to analyze the soybean production system in Benin. Data were collected from 324 soybean producers selected from the three major soybean-producing agro-ecological areas i.e. agro-ecological zone 3 (southern Borgou), agro-ecological zone 4 (West Atacora) and agro-ecological zone 5 (Cotton zone of the Centre of Benin). A participatory research approach with group discussions followed by individual interviews was carried out for extracting the information from respondents. Information mainly referred to the socio-demographic characteristics of soybean producers, production practices, extent of yields and constraints. Descriptive statistics were then used to analyze the data. Ordered Probit regression was further carried out to assess the determinants of soybean yield levels in Benin. Results of this study revealed that soybean producers of the three agro ecological zones have most of the common demographic characteristics. They equally revealed that farmers do not follow correct soybean cropping practices. Improved seeds, plant density, fertilizers, fallow, and sex of farmers have significantly $(\mathrm{P}<0.05, \mathrm{P}<0.01, \mathrm{P}<0.001)$ influenced the yields of soybean in Benin. Within the context of sustainable agricultural production practices, it is recommended to develop appropriate technologies for soybean cultivation. The extension services should focus more on the appropriate combination of input resources which are found to contribute more to the soybean production.
\end{abstract}

* Corresponding author

E-mail: phoungnandan@yahoo.com (Pascal Houngnandan)

Peer review under responsibility of Journal of Experimental Biology and Agricultural Sciences.

Production and Hosting by Horizon Publisher (www.myvision.webs.com/horizon.html)

All rights reserved.
All the article published by (Journal of Experimental Biology and Agricultural Sciences) / CC BY-NC 4.0

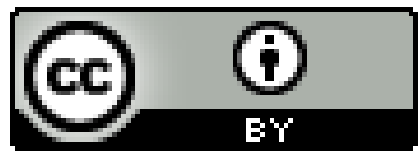




\section{Introduction}

Soybean [Glycine $\max$ (L.) Merril], as an important source of vegetable and oil for human and animal consumption (Couto et al., 2011), is highly quoted on the world market (Abbasi et al., 2010). Soybeans seeds account to 56\% of global oilseed production (Wilson, 2008). As one of the most important legumes species, soybean contains about $40 \%$ highly nutritious protein with all essential amino acids compared to others (Raghuvanshi \& Bisht, 2010). It is also rich in oligo-elements such as magnesium, phospholipids, vitamins and minerals (Ali, 2010). Therefore, it is a very interesting crop for vegans. In addition to its nutritional values, soybean is also used as important nitrogen $\left(\mathrm{N}_{2}\right)$-fixing crop throughout the world for the restoration and maintenance of soil fertility in a sustainable way and consequently the improvement of crop yields (Smaling et al., 2008).

There is a great deal of growing production and utilization of soybean. Global soybean production in the first decade of the 20th century was only about 22 million tons while this value escalated to more than ten times and now in the first decade of the $21^{\text {st }}$ century it is about 223 million tons (Ali, 2010).

In Benin, from last few decades the interest in soybean cultivation has increased among farmers. In the same vein, total land coming into soybean cultivation has increased from 10173 ha to 95106 ha from 2004 to 2013 respectively. However, total yield was reported less than $700 \mathrm{~kg}$ dry matter (DM) per hectare (DPP/MAEP, 2014).

Cropping practices such as tillage, time and method of sowing, plant density, plant geometry, mulching, intercropping, water management, nutrients and weed management may determine soybean productivity by affecting its growth and development, disease and pest infestation (Singh et al., 2010). Soybean plants are highly susceptible to physical, chemical and biological conditions of soil along with climatic conditions (Ohyama et al., 2009). Soybean seed' yields often severely decline with pest, insects, and weeds infestation. The control of agronomic practices could help to produce high crop yields and could also reduce the costs of production by utilizing resources and inputs judiciously and taking care of the environment. Consequently, it is important to describe and analyze the soybean production system in Benin in order to identify the main factors that are reducing yields. Therefore, the objectives of this study are to describe soybean production systems and to identify determinants of soybean production systems in Benin.

\section{Materials and Methods}

\subsection{Study areas}

Present investigation was carried out in the three agroecological zones of the North and the Centre of Benin. The study agro-ecological zones are agro-ecological zones 3,4 , and 5. Among these, the agro-ecological zone 3 (Food-producing zone of southern Borgou) and the agro-ecological zone 4 (West Atacora zone) belong to the Sudanese zone and are located between $1^{\circ} 10^{\prime}-3^{\circ} 45^{\prime} \mathrm{E}$ and $9^{\circ} 45^{\prime}-12^{\circ} 25^{\prime} \mathrm{N}$. These two zones are characterized by a unimodal rainfall with an average annual rainfall less than $1000 \mathrm{~mm}$. The relative humidity varies from 18 to $99 \%$ while temperature fluctuates from 24 to $31^{\circ} \mathrm{C}$, but could attain a maximum of $40^{\circ} \mathrm{C}$. The Sudanese zone is a woodland and savanna region with either ferruginous soils or lithosols or fluvisols. Maize, sorghum, millet, yam, and groundnut are annual crops, and cotton and soybean are cash crops.

The Agro-Ecological Zone 5 (Cotton zone of the Centre of Benin) is in the sudano-guinean zone and located between $1^{\circ} 45^{\prime}-2^{\circ} 24^{\prime} \mathrm{E}$ and $6^{\circ} 25^{\prime}-7^{\circ} 30^{\prime} \mathrm{N}$. The annual mean temperature is between $26^{\circ} \mathrm{C}-29^{\circ} \mathrm{C}$ and the average annual rainfall is ranging from 1000 to $1400 \mathrm{~mm}$. The relative humidity varies from $69 \%$ to $97 \%$. The soils are either deep ferrallitic or vertisols. Vegetation is of a degraded woody savannah type. Maize, yam, cassava and groundnut are annual crops, and cotton and soybean are cash crops.

\subsection{Sampling method}

The size of the sample of soybean producers was determined using the normal approximation of binomial variable (Dagnelie 1998)

$\mathrm{N}=\left[\left(\mathrm{U}_{1-\alpha / 2}\right)^{2} \times \mathrm{p}(1-\mathrm{p})\right] / \mathrm{d}^{2}$

Whereas $\mathrm{N}=$ number of soybean producers to be surveyed; $\mathrm{p}$ is the proportion of individuals who produced soybean. It was computed by randomly investigating 100 people in the area during an exploration stage. Among the 100 individuals, 30\% of respondents have knowledge of soybean cultivation. $\mathrm{U}_{1-\alpha / 2}=$ 1.96 is the normal random variable value for a probability value of $\alpha=0.05 ; \mathrm{d}$ is the expected error margin of any parameter to be computed from the survey, which is fixed at $5 \%$ in this study. Under these assumptions, 324 soybean producers were selected in the study area. Three districts from each Agro Ecological Zone are selected on the basis of their contribution in the total volume of soybean produced in Benin and their accessibility (Figure 1). The number of respondents per district is proportional to the contribution of each district to the total quantity of soybean produced. Seven villages are randomly selected per zone. In each village, a list of soybean producers is obtained with the help of the village chief and extension officers.

\subsection{Data collection}

Data were collected from September 2012 to March 2013. Semi-structured interviews with groups, participatory exercises (brainstorming, prioritization, and problem analysis) and open discussions in a group setting were used to increase knowledge on existing cultivation practices and to identify production constraints. 


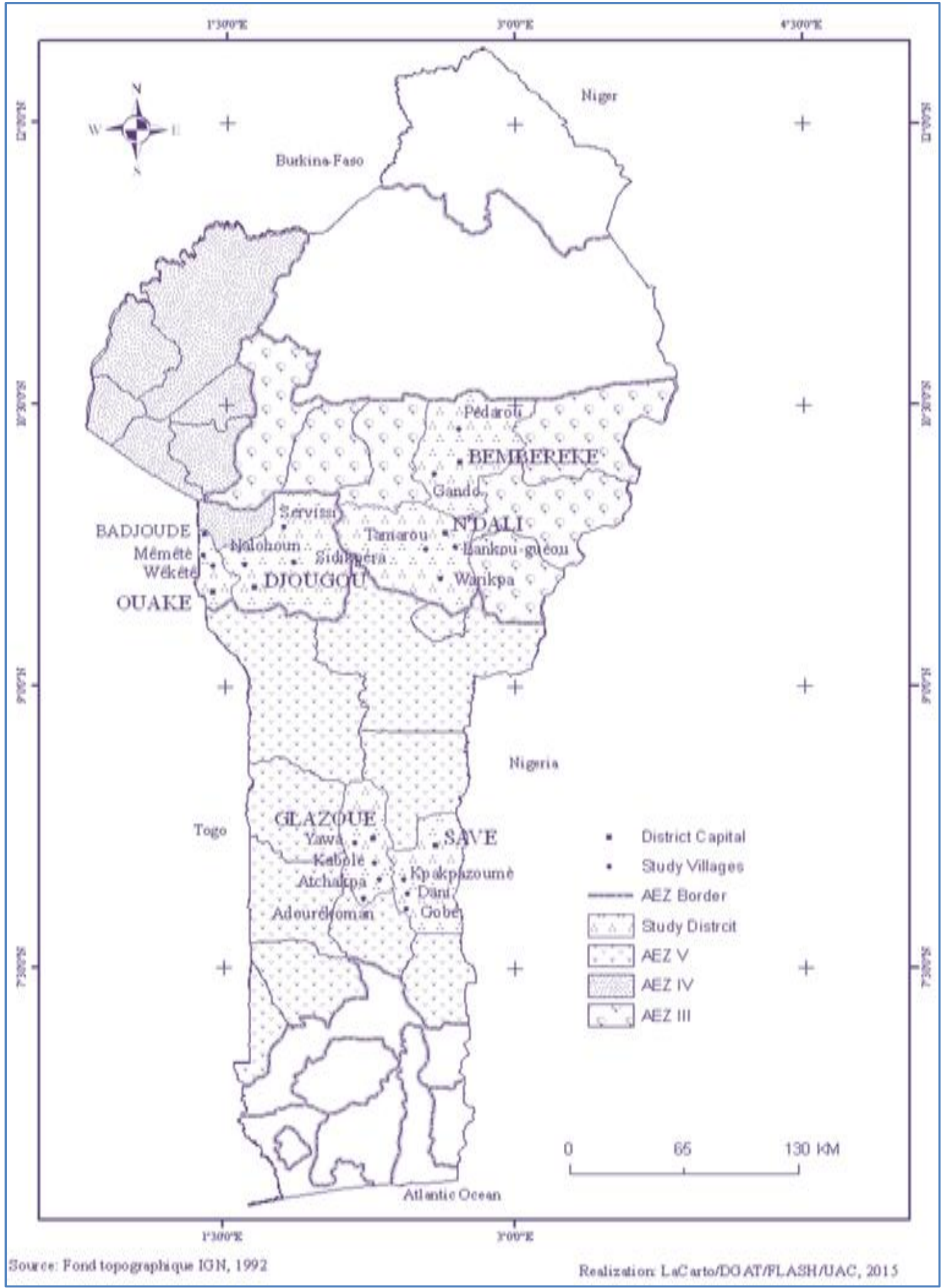

Figure 1 Localization of the surveyed areas in Benin. 
Table 1 Socio-demographic characteristics of the respondents.

\begin{tabular}{|c|c|c|c|c|}
\hline \multirow[t]{2}{*}{ Socio-demographic characteristics } & \multirow[t]{2}{*}{ Modality } & \multicolumn{3}{|c|}{ Percentage of Respondents } \\
\hline & & Zone 3 & Zone 4 & Zone 5 \\
\hline \multirow[t]{2}{*}{ Sex } & Male & 66.7 & 63.9 & 60.5 \\
\hline & Female & 33.3 & 36.1 & 39.5 \\
\hline \multirow[t]{3}{*}{ Age } & $<25$ years old & 30.0 & 28.2 & 12.0 \\
\hline & Between 25 - 50 years & 62.5 & 65.7 & 72.6 \\
\hline & $>50$ and above & 7.5 & 6.1 & 15.4 \\
\hline \multirow[t]{3}{*}{ Education } & Not literate & 58.5 & 59.1 & 64.2 \\
\hline & Primary school & 16.3 & 17.1 & 28.2 \\
\hline & Secondary school & 13.6 & 15.6 & 13.6 \\
\hline \multirow{2}{*}{$\begin{array}{l}\text { Origin of the } \\
\text { respondent }\end{array}$} & Native & 87.8 & 90.2 & 96.0 \\
\hline & Not native & 12.2 & 9.8 & 4.0 \\
\hline \multirow{3}{*}{$\begin{array}{l}\text { Experience in } \\
\text { soybean cultivation }\end{array}$} & $<5$ years old & 8.7 & 9.3 & 9.7 \\
\hline & Between $5-10$ years old & 71.5 & 66.7 & 71.6 \\
\hline & $>10$ years and more & 21.7 & 24.0 & 18.8 \\
\hline \multirow[t]{3}{*}{ Area of soybean cultivated } & $<1 \mathrm{ha}$ & 39.5 & 36.2 & 14.1 \\
\hline & Between 1 et 5 ha & 59.2 & 62.7 & 84.2 \\
\hline & $>5$ ha & 1.4 & 2.9 & 1.7 \\
\hline \multirow[t]{2}{*}{ Peasant organisation membership } & Yes & 72.8 & 71.4 & 70.6 \\
\hline & No & 27.2 & 28.6 & 29.4 \\
\hline \multirow[t]{2}{*}{ Extension service } & Yes & 21.8 & 23.7 & 36.2 \\
\hline & No & 78.2 & 76.3 & 63.8 \\
\hline \multirow[t]{2}{*}{ Credit access } & Yes & 19.8 & 21.6 & 25.5 \\
\hline & No & 80.2 & 78.4 & 74.5 \\
\hline
\end{tabular}

Source: Field survey (September 2012 and March 2013)

During in-depth phase of data collection, questionnaires are focused on socio-demographic characteristics of soybean producers, production practices, inputs, yields and constraints. Field observations are used to supplement and validate the surveyed variables and information gathered during group discussions.

\subsection{Data analysis}

Descriptive statistics such as frequencies and means are carried out using Statistical Package for the Social Sciences (SPSS), Version 16.0. In order to assess the determinants of soybean yield level in Benin, an ordered Probit regression model is preformed using SPSS (Statistical Package for the Social Sciences) version 16.0.

The model can be written in the form:

$\forall \mathrm{k} \in(1,2,3), \mathrm{Y}_{\mathrm{i}}=\mathrm{k} \Leftrightarrow \mathrm{S}_{\mathrm{k}}\left\langle\mathrm{Y}_{\mathrm{i}}^{*}=\mathrm{X}_{\mathrm{i}} \beta+\mu_{\mathrm{i}} \leq \mathrm{S}_{\mathrm{k}+1}\right.$ with $\mu_{\mathrm{i}} \sim N$ $\left(0, \sigma^{2}\right)$ (Damisa \& Yohanna, 2007).
Whereas $\mathrm{Yi}^{*}$ is the propensity of each producer to have high yield and $\mathrm{Yi}$ is the categorical variable with three modalities that describes the level of yield $\left[1=\right.$ low $\left(<700 \mathrm{~kg} \mathrm{ha}^{-1}\right), 2=$ medium (between 700 and $\left.1000 \mathrm{~kg} \mathrm{ha}^{-1}\right), 3=$ high $(>1000 \mathrm{~kg}$ $\left.\mathrm{ha}^{-1}\right)$ ]. The residue $\mu_{\mathrm{i}}$, assumed to follow a standard normal distribution $N(0,1)$, is interpreted as the unobservable component of the propensity for each farmer to obtain a high yield. When this propensity is low, less than the threshold $S_{1}$ $\left(\mathrm{S}_{1}=-\infty<\mathrm{Y}_{\mathrm{i}}^{*} \leq \mathrm{S}_{2}\right)$, the farmer has low yield level and $\mathrm{Y}_{\mathrm{i}}=1$. When this tendency is between the two thresholds S1 and S2 $\left(S_{2}<Y_{i}^{*} \leq S_{3}\right)$, the producer is in medium yield, and in this case $Y_{i}=2$.

When the producer has high level of propensity, i.e. when it is greater than the threshold $\mathrm{S} 2\left(\mathrm{~S}_{3}<\mathrm{Y}_{\mathrm{i}}{ }^{*} \leq \mathrm{S}_{4}=+\infty\right)$, it has a high yield level and $\mathrm{Yi}=3$. The two thresholds $\mathrm{S} 1$ and $\mathrm{S} 2$ are unknown and must be estimated. In order to identify the model, it is necessary to standardize the constant term $X_{1} \beta$ zero and the residue variance $\mu_{\mathrm{i}}$.

The empiric form of the equation $Y_{i}^{*}=X_{i} \beta+\mu_{i}$ can be written in the form (Dedehouanou et al., 2014):

$$
\begin{gathered}
\text { YIELDLEVEL } L_{i}=\text { SEX } \beta_{1}+A G E \beta_{2}+\text { HHAGRICLAB } \beta_{3}+E D U C \beta_{4}+\text { EXTENSIONSV } \beta_{5}+\text { VARIMPROV } \beta_{6}+\text { PLTDENSITY } \beta_{7} \\
+ \text { FERTILIZER } \beta_{8}+\text { FALLOW } \beta_{9}+\mu \mathrm{i}
\end{gathered}
$$


[Whereas YIELDLEVEL $=$ dependant variable designing soybean yield level of producers (where $1=$ low level, $2=$ mean level, $3=$ high level); SEX = sex of the producers $(1=$ male, $0=$ female $)$ HHAGRICLAB $=$ number of agricultural actives; EDUC $=$ Number of years of formal schooling of the soybean producer $(1=$ none; $2=$ primary school; $3=$ secondary school cycle $1 ; 4=$ secondary school cycle 2 ; 5=University); EXTENSIONSV $=$ contact with extension service $(1=$ yes; $0=$ otherwise $)$; VARIMPROV $=$ use of improved seed $(1=$ yes; $0=$ otherwise $)$ PLTDENSITY = plant density per hectare $(1=250.000 ; 2=200.000 ; 3=133.333 ; 4=107.142$ 5=other $)$; FERTILIZER $=$ use of fertilizer $(1=$ yes; $2=$ otherwise $) ;$ FALLOW $=$ practice of fallow $(1=$ yes $; 2=$ otherwise $)]$

Table 2 Soybean cultivation practices.

\begin{tabular}{|c|c|c|c|c|}
\hline \multirow[t]{2}{*}{ Variables } & \multirow[t]{2}{*}{ Modality } & \multicolumn{3}{|c|}{ Percentages of respondents } \\
\hline & & Zone 3 & Zone 4 & Zone 5 \\
\hline \multirow[t]{4}{*}{ Crops in rotation with soybean } & Maize & 67.8 & 64.2 & 67.5 \\
\hline & Sorghum & 25.6 & 34.1 & 12.3 \\
\hline & Bean & 38.5 & 34.3 & 39.2 \\
\hline & Groundnut & 7.9 & 8.5 & 12.1 \\
\hline \multirow[t]{2}{*}{ Crops intercropped with soybean } & Maize & 2.6 & 3.4 & 22.6 \\
\hline & Sorghum & 1.2 & 0.7 & 0.2 \\
\hline \multirow{4}{*}{$\begin{array}{l}\text { Seed purveyance } \\
\text { Source }\end{array}$} & Fludor & 2.3 & 1.4 & 7.9 \\
\hline & $\mathrm{CeCPA}$ & 12.9 & 16.3 & 19.2 \\
\hline & Market & 38.7 & 49.0 & 43.5 \\
\hline & Previous harvest & 48.2 & 43.5 & 50.8 \\
\hline \multirow{3}{*}{ Cultivated Soybean variety } & Local variety & 80.7 & 78.9 & 81.7 \\
\hline & Improved variety & 23.8 & 22.4 & 36.0 \\
\hline & Improved variety & 3.7 & 4.1 & 0 \\
\hline \multirow[t]{2}{*}{ Types of plowing } & Plat plowing (zero tillage) & 60.8 & 63.3 & 0 \\
\hline & Ridge plowing & 39.2 & 36.1 & 100 \\
\hline \multirow{9}{*}{$\begin{array}{l}\text { Space between rows and inter-plant } \\
\text { spacing }\end{array}$} & $40 \mathrm{~cm} \times 20 \mathrm{~cm}$ & 11.9 & 17.7 & 0.6 \\
\hline & $60 \mathrm{~cm} \times 25 \mathrm{~cm}$ & 43.1 & 42.2 & 1.1 \\
\hline & $70 \mathrm{~cm} \times 25 \mathrm{~cm}$ & 31.9 & 32.7 & 0.6 \\
\hline & $50 \mathrm{~cm} \times 20 \mathrm{~cm}$ & 4.7 & 5.4 & 5.1 \\
\hline & $80 \mathrm{~cm} \mathrm{x} 40 \mathrm{~cm}$ & 8.7 & 2.0 & 15.4 \\
\hline & $80 \mathrm{~cm} \times 30 \mathrm{~cm}$ & 1.9 & 1.5 & 15.4 \\
\hline & $80 \mathrm{~cm} \times 20 \mathrm{~cm}$ & 1.7 & 2.0 & 44.4 \\
\hline & $80 \mathrm{~cm} \times 25 \mathrm{~cm}$ & 8.6 & 7.1 & 0.7 \\
\hline & $80 \mathrm{~cm} \mathrm{x} 15 \mathrm{~cm}$ & 3.1 & 2.0 & 0.7 \\
\hline \multirow[t]{4}{*}{ Number of seed per hole } & 5 & 70.2 & 73.5 & 6.3 \\
\hline & 6 & 23.1 & 17.0 & 43.1 \\
\hline & 7 & 5.3 & 4.1 & 32.2 \\
\hline & 8 & 3.9 & 4.1 & 14.4 \\
\hline \multirow[t]{2}{*}{ Number of plants per hole } & 2 & 78.9 & 84.4 & 13.9 \\
\hline & 3 & 12.7 & 10.9 & 49.7 \\
\hline \multirow[t]{2}{*}{ Seed inoculation } & Yes & 0 & 0 & 0 \\
\hline & No & 100 & 100 & 100 \\
\hline
\end{tabular}

Source: Field survey (September 2012 and March 2013)

Table 3 Farmers' yield level distribution

\begin{tabular}{|c|c|c|}
\hline Yield level & Frequency & Percent \\
\hline Low $\left(<700 \mathrm{~kg} \mathrm{ha}^{-1}\right)$ & 196 & 60,5 \\
\hline Medium (between 700 and $1000 \mathrm{~kg} \mathrm{ha}^{-1}$ ) & 91 & 28,1 \\
\hline $\operatorname{High}\left(>1000 \mathrm{~kg} \mathrm{ha}^{-1}\right)$ & 37 & 11,4 \\
\hline Total & 324 & 100,0 \\
\hline
\end{tabular}

Source: Field survey (September 2012 and March 2013) 


\begin{abstract}
435 3 Results

3.1 Socio-demographic characteristics of the respondents

Table 1 provides socio-demographic characteristics of soybean producers in the three Agro Ecological Zones. The majority of respondents are males (64\% of male against $36 \%$ of female). Most of them are married (85\%) and are from 25 to 50 years old. The majority of them are native $(91 \%)$ and illiterate $(61 \%)$. Furthermore, Most of the surveyed respondents have 510 years soybean production experience and have cultivated 1 to 5 hectares of soybean in year $2012.72 \%$ of the respondents belong to farmers' organization and most of them have no access to extension services (73\%).
\end{abstract}

\subsection{Production factors}

Heritage is the dominant mode of land acquisition followed by donation ( $78 \%$ and $22 \%$ of the respondents) in the three Agro Ecological Zones. $100 \%$ of respondents use family labor for soybean cultivation. The main activities carried out by family labor are basically sowing, harvesting, plugging and winnowing. In addition to family labor, the use of occasional hired labor depends on the agro-ecological area. Indeed, hired labor is more practiced in the central region $(90.53 \%)$ than in the two northern regions ( $47 \%$ and $49 \%$ in zone 3 and zone 4 respectively) and is mainly used for clearing and plowing. The costs of clearing vary from 10000 to 25000 FCFA / ha in the three study areas. Labor prices vary from 12500 to 30000 FCFA per ha in the central region and from 20000 to 40000 FCFA in both northern regions.

For sowing most of the surveyed respondents in these three study areas $(90 \%)$ use previous season harvest seed or buy seeds in the near markets. Only $24 \%$ of them buy from FUPRO (Fédération de l'Union des Producteurs du Bénin) or CARDER (Centre d'Action Régionale pour le développement agricole). Furthermore, local variety namely "Jupiter" is highly popular and widely cultivated in all three areas (82\%). Two improved varieties are used, but their names are unknown to the producers. The only criterion at hand to differentiate between local and improved varieties is the size of grain. Thus, the improved varieties are called "gros grain" and "grain moyen". The majority of farmers (78\%) do not have easy access to formal and / or informal credit to finance agricultural activities.

\subsection{Cropping practices}

Table 2 presents the cropping practices used by soybean producers in the three Agro Ecological Zones. Soybean could be grown in rotation with maize, sorghum, bean and groundnut and could be intercropped with maize and sorghum. In zone 5, all the studied respondents $(100 \%)$ plow on ridges while in zones $4 \& 3$ this is not a common practice and $62 \%$ of the surveyed respondents use flat plowing (zero tillage) against
$37.6 \%$ who carry on the ridges. In zone 5, soybean crops is sown from June $15^{\text {th }}$ to July $31^{\text {st }}$ of every year, while in zones 4 and 3 sowing is carried out from July $1^{\text {st }}$ to August $15^{\text {th }}$ of each year. Direct sowing in pocket is adopted in all the study areas. Seeding density adopted by producers varies according to the three areas. In zone 5, it is variable and may be $80 \mathrm{~cm} \times 20 \mathrm{~cm}$, $80 \mathrm{~cm} \times 30 \mathrm{~cm}$ or $80 \mathrm{~cm} \times 40 \mathrm{~cm}$.

Furthermore, in zones 4 and 3, producers used ridge plowing (tillage) practices with the spacing of $70 \mathrm{~cm} \times 25 \mathrm{~cm}$, while those who do flat plowing (zero tillage) adopt the spacing of 60 $\mathrm{cm} \times 25 \mathrm{~cm}$. In these three study areas, 5 to 8 seeds have been sown per hill but hardly between 2 and 3 germinate. None of the producers inoculates soybean seed with Rhizobium strains before sowing, while $95 \%$ of producers do not provide manure to soybean cultivation. Indeed, $73 \%$ of respondents perceive that soybean crop does not need fertilizers for growth and $37 \%$ are faced to a lack of financial means to purchase specific fertilizers for soybean. However in the northern regions, $9 \%$ of the producers use cotton NPK fertilizers at a rate ranging from 5 and $10 \mathrm{~kg}$ per ha. Soybean is harvested 3-4 months after planting depending on the variety. About soybean ravagers, farmers complain about the attack of soybean fields by rodents ( $82 \%$ of respondents), insects (32\% of respondents) and birds (24\% of respondents) in all investigated areas. Rodent (rat, hare) and insects (locusts) attack during the vegetative and flowering stage of soybean by destroying the leaves and flowers. Birds attack immediately after seed emergence and at the pods maturation stage. Producers use endogenous methods (use of traps against nocturnal rodents, and scarecrow against birds) to control ravagers. At harvest, the majority of respondents $(99.4 \%)$ use jute bags as a storage material.

\subsection{Determinants of soybean yield level in Benin}

Table 3 shows that $60.5 \%, 28.1 \%$ and $11.4 \%$ of the soybean producers in Benin had low $\left(<700 \mathrm{~kg} \mathrm{ha}^{-1}\right)$, medium (between 700 and $\left.1000 \mathrm{~kg} \mathrm{ha}^{-1}\right)$ and high (>1000 $\mathrm{kg} \mathrm{ha}^{-1}$ ) yield level respectively. The factors which determine soybean yield level in Benin are presented in table 4 . The parameters cut 1 and cut 2 denote thresholds S1 and S2 of the model. Thus, the threshold values cut 1 and cut 2 indicate the propensity to have a high level of yield. When this propensity is low (less than 1.42519 as in cut1), producers have a low level of yield. When this value is between 1.42519 and 6.187963 (cut2), they had a medium level of yield and when this value is greater than 6.187963 , they had high level of yield as reported from the producers' fields.

Based on the model results, the null hypothesis (at 1\%) according to which "the two cut points are equal" has been rejected in the present study (cf. test of cut 1 and cut2). Hence, they are statistically different and the results allow concluding on the difference that can be observed from the low value to the high one of the yield level. 
The equation $Y_{i}^{*}=X_{i} \beta+\mu_{i}$ can be written in the form:

$$
\begin{aligned}
\text { YIELDLEVEL }_{i}= & 0.8904464 \text { SEX }-0.0096934 \text { AGE }+0.0301956 \text { HHAGRICLAB }-0.1292693 \text { EDUC } \\
& +0.3962988 \text { EXTENSIONSV }+3.71192 \text { VARIMPROV }+2.62314 \text { PLTDENSITY }+4.074051 \text { FERTILIZER } \\
& +2.241636 \text { FALLOW }+0.383652
\end{aligned}
$$

\begin{tabular}{|c|c|c|c|c|}
\hline \multicolumn{5}{|c|}{ Dependent variable : Yield level $(1=l o w, 2=$ medium, $3=$ high $)$} \\
\hline Independent variables & Coef. & Std. Err. & $\mathrm{Z}$ & $\mathrm{P}>\mathrm{Z}$ \\
\hline Constant & 0.383652 & 0.423 & 1.90 & 0.000 \\
\hline Sex & 0.8904464 & 0.3528024 & 2.52 & 0.012 \\
\hline Age & -0.0096934 & 0.0119246 & -0.81 & 0.416 \\
\hline Number of agricultural actives & 0.0301956 & 0.0397539 & 0.76 & 0.448 \\
\hline Education & -0.1292693 & 0.1656711 & -0.78 & 0.435 \\
\hline Extension contact & 0.3962988 & 0.3336188 & 1.19 & 0.235 \\
\hline Use of improved seed & 3.71192 & 0.4659066 & 7.97 & 0.000 \\
\hline Plant density & 2. 62314 & 0.048704 & 0.96 & 0.001 \\
\hline Fertilizer & 4.074051 & 0.851975 & 4.78 & 0.000 \\
\hline Fallow & 2.241636 & 0.5691131 & 3.94 & 0.000 \\
\hline /cut1 & 1.42519 & 0.6123683 & & \\
\hline /cut2 & 6.187963 & 0.7939732 & & \\
\hline
\end{tabular}

Table 4 Determinants of the soybean yield level in Benin using ordered logistic regression model.

test_b[/cut1]=_b[/cut2]; ( 1) [cut1]_cons $-[$ cut2]_cons $=0 ;$ chi2 $(1)=76.03 ;$ Prob $>$ chi2 $=0.0000$

[Source: Field survey (September 2012 and March 2013)].

Yield level is significantly determined (less than $5 \% ; \mathrm{P}<0.012$ ) by gender issues. Technical factors such as the use of improved soybean varieties, the use of fertilizers, the plant density and the practice of fallow in the cropping system have significantly $(\mathrm{P}<0.001)$ and positively determined the level of yields.

\section{Discussions}

4.1 Socio-demographic characteristics of soybean producers and production factors

Results of study revealed that soybean cultivation is dominated by men. This could be due to the fact that only men are landowners and can inherit land from their parents (Saïdou et al., 2007). The few women farmers involved in soybean production have acquired the land from their husbands. The majority of respondents are married. This indicates that they are responsible and could take charge of their families. Respondents are from 25 to 50 years old. This implies that soybean producers are young and will cultivate this crop the next one, two or three decades if they are attracted. Similar results are reported by Dogbe et al. (2013) from Ghana and conclude that soybean production has promising future if these relatively young farmers could be motivated to remain in the sector. Furthermore, Ebong et al. (2011) report a positive relationship between ages and technical efficiency improvement in urban crop production. This is allowing for a strong correlation between ages of the producers and their ability and willingness to improve cultivation practices if appropriate extension services are provided. No significance of extension services may be probably due to the almost zero access of surveyed soybean producers to extension services (73\%). Although some authors reported that producers who have access to extension contact will perform better than those who are not visited by extension agents (Ezeh et al., 2012; Balogun et al., 2012), it is noticed here that the involvement of soybean producers in farmers organization denotes a form of social participation which is positively related to farmers decision to adopt new technologies (Omobolanle et al., 2007). Indeed, most of them are involved in farmers' organization.

Low literacy rate was reported among the respondents of these studied areas. This could reduce the adoption of improved farming technologies. Indeed, Eze et al. (2006), Ofuoku et al. (2008), Koskei et al. (2013) reported that literacy level determined the adoption of improved production technologies by farmers since literate farmers could quickly understand agricultural instructions than the illiterate farmers.

Farmer's experiences in soybean cultivation vary from 5 to 10 years. On the one hand, the few years of experience could be due to the fact that farmers are recently interested in the soybean sector. On the other hand, most of the respondents cultivated 1 to 5 hectares of soybean in year 2012 and have constantly increased the area under cultivation every year. This is confirmed in DPP/MAEP (2014) that indicated the increase of soybean production statistics from 5535 tons in year 2004 to 96944 tons in year 2013. According to the respondents, soybean productions become interesting after the recent dysfunctions in the cotton sector. Then, as a cash crop it is 
worth stressing that soybean has its concurrent crop, cotton. Therefore, any successful reforms in the cotton sector are to impede most achievements in the soybean sector and the reverse is also true.

Heritage is the dominant mode of land acquisition in the three zones indicating that land belongs to natives. The same results were found by Balogoun et al. (2014) in cashew's production systems of Benin. Family labor was used by $100 \%$ of respondents in the three zones. But occasional hired labor was more used in the Centre than in the North. On the one hand, this situation could be due to the fact that family labor was used for easy works such as sowing, harvesting, plugging and winnowing. Since farmers from the central region used to sown soybean on ridges (difficult work) they could need more hired labor than those of the North. On the other hand, this situation could be due to the high cost of hired labor in the North (between 20,000 and 40,000 FCFA) compared with that of the Centre (between 12,500 and 30,000 FCFA).

Majority of farmers in Benin obtained their seed from informal sources (previous harvest seed, market). Availability of quality seeds in Benin is one of the major constraints on the intensification of sustainable crop production (Achigan-Dako et al., 2014). Improving the delivery of adapted seeds is one important issue to ensure reliability in the input sector and to enhance extension services to producers.

4.3 Cropping practices and determinants of soybean yield level in Benin

Soybean is mainly cultivated in rotation or as an intercrop to cereal and producers already notice that soybean has a fertilizing effect on succeeding cereal crop. On the one hand, the rotational system is based upon the scientific evidence that legumes planted in the first year will leave some nitrogen in the soil which will subsequently be fixed by the cereal crop in the next season and therefore will increase the potential yield of the cereal crop in that season unlike the continuous cereal system (Kabuli et al., 2005). On the other hand, as an intercrop with cereal crops, such as maize or sorghum, soybean provides a strategy for crop diversification, food security, and soil fertility replenishment.

Seeding rates and plant populations for soybeans adopted in the three zones are very low (between 100000 and 200000 plants/ha) compared to those recommended (300000 to 550000 plants/ha) (Cetiom, 2012). Liu et al. (2006) and Liu et al., 2008) reported that application of appropriate plant density help reducing the time required for canopy closure, improving crop growth and consequently biomass and grain yield of soybean production systems. Although most of the soils used to cultivate soybean in Benin are degraded, producers in their majority do not use fertilizers to improve soil fertility level and they still claim that soybean does not need fertilizers for growth. However, several studies show the positive effect of using fertilizers in soybean cultivation (Akpalu et al., 2014; Tairo \& Ndakidemi, 2014). Nevertheless, even if some producers recognize the importance of fertilizers, they are faced with a lack of financial resources to purchase those inputs. Facing a persistent high cost of chemical fertilizers, the valorization of rhizobial inoculation is recommended (Houngnandan et al., 2009; Akpalu et al., 2014). But, the results at hand here provide no evidence of producers inoculating soybean seeds with Rhizobia bacteria before sowing. This situation could be explained by their ignorance of such a technology.

Pests such as rodents, insects and birds are the principal soybean ravagers in Benin. Belfield et al. (2011) reported that soybean yields could be significantly reduced if pests were not effectively managed. They also indicated that the presence of pests does not automatically mean that control is needed. So, farmers have to check before if the damage is significant. No disease is mentioned by farmers. Similar results are found by Mafongoya et al. (2009) who showed that soybean crop had a low susceptibility to diseases.

The soybean grain yields obtained after harvest are inferior to $1000 \mathrm{~kg} \mathrm{ha}-{ }^{1}$ for the majority of respondents. Yields are lower than those obtained elsewhere and reported by several authors (from 2200 to $7610 \mathrm{~kg} \mathrm{ha-}^{1}$ ) when soybean crop is well managed (Javaheri \& Baudouin, 2003; Akpalu et al., 2014).

Soybean seed yield in Benin is determined by plant density, fallow, improved seed and sex. The coefficient of variable plant density is significant and positive. This indicates that producers, who adopt high densities, could increase their production. The coefficient of variable fallow is significant and positive indicating that producers who cultivate soybean after a fallow will get better yields. The variable "improved seed" has a significant and positive coefficient. This means that the increase of soybean production will depend on the use of improved seed. Si \& Wang (2011) found the same results and showed that soybean yields could increase by approximately 11 and $13 \%$, when any of the two input factors (seed and fertilizer) increase qualitatively by $10 \%$. Belfield et al. (2011) reported that the yield and quality of the soybean crop could depend on the choice of an appropriate variety. The estimated positive coefficient for variable sex was tentatively to assert that men tend to be more technically efficient than women. The same results were found by Otitoju \& Arene (2010).

\section{Conclusion}

Soybean is an important cash crop for farmers in Benin. In spite of this, this crop is mismanaged. Constraints to soybean production include mainly inadequate cropping practices. Appropriate technical advices on production need to be developed to support the production of this crop by a wider group of producers. There is the need to improve promotion and dissemination of improved soybean technologies such as seeds, fertilizers and inoculants. Agricultural extension services and development workers should encourage farmers to improve their management practices. Government and its development partners can improve the access to inputs and 
financial services. Availability of seeds and other crucial inputs are very vital if the speed of adoption of the technology is to be improved. Development of new formal and informal systems of seed delivery programs such as seed multiplication projects and commercial outlets need to be explored.

\section{Acknowledgements}

This work is co-funded by the International Atomic Energy Agency (AIEA) through it's TC Project BEN/5/007 "Soil, Crop and Livestock Integration for Sustainable Agriculture Development through the Establishment of a National Laboratory Network" and the Competitive fund Project of the University of Abomey-Calavi "PROSAEI (AgricultureFarming Integrated Productivity Systems)". The authors are indebted to the local people for their availability and their help during the data collection phase. They are also grateful to Balogoun Ibouraïman and Agossou Désiré for technical assistance.

\section{Conflict of interest}

Authors would hereby like to declare that there is no conflict of interests that could possibly arise.

\section{References}

Abbasi MK, Manzoor M, Tahir MM (2010) Efficiency of Rhizobium inoculation and $\mathrm{P}$ fertilization in enhancing nodulation, seed yield, and phosphorus use efficiency by field grown soybean under hilly region of Rawalakot Azad Jammu and Kashmir, Pakistan. Journal of Plant Nutrition 33 : 1080 1102. doi: $10.1080 / 01904161003729782$

Achigan-Dako EG, Houdegbe AC, Glele M, Nono-Womdim R (2014) Analyse du système de production et de distribution des semences de maïs (Zea mays L.) au Sud-Bénin. Biotechnology Agronomy Society and Environment 18: 49-60

Akpalu MM, Siewobr H, Oppong-Sekyere D, Akpalu SE (2014) Phosphorus Application and Rhizobia Inoculation on Growth and Yield of Soybean (Glycine max L. Merrill). American Journal of Experimental Agriculture 4: 674-685

Ali N (2010) Soybean Processing and Utilization. In Singh G (ed,) The Soybean: Botany, Production and Uses, CAB International, USA., ISBN: 9781845936457, pp: 345-374.

Balogoun I, Saidou A, Ahoton EL, Amadji GL, Ahohuendo CB, Adebo JB, Babatoundé S, Chougourou D, Adoukonou SH, Ahanchédé A (2014). Caractérisation des systèmes de production à base d'anacardier dans les principales zones de culture au Bénin. Agronomie africaine 26 : 9-22.

Balogun OL, Adeoye A, Yusuf SA, Akinlade RJ, Carim-Sanni, A (2012) Production Efficiency of Farmers under National Fadama II Project in Oyo State, Nigeria. International Journal of Agricultural Management \& Development, 2: 11-24.
Belfield S, Brown C, Martin M (2011) A guide to upland cropping in Cambodia: soybean. ACIAR Monograph No. 146. Australian Centre for International Agricultural Research, Canberra, Australia

Cetiom (2012) Available on (http://www.terresinovia.fr/fileadmin/cetiom/kiosque/PDF_fic hes_TK/brochure_SO2012.pdf. Access on 16/09/2015.

Couto C, Silva LR, Valentão P, Velázquez E, Peix A, Andrade PB (2011) Effects induced by the nodulation with Bradyrhizobium japonicum on Glycine max (soybean) metabolism and antioxidant potential. Food Chemistry 127 :1487-1495. doi:10.1016/j.foodchem.2011.01.135.

Dagnelie P (1998) Statistique théorique et appliquée. Tome 2 : Inférences statistiques à une et deux dimensions. De Boeck et Larcier, Paris-Bruxelles, France Belgique.

Damisa MA, Yohanna M (2007) Role of Rural Women in Farm Management Decision Making Process: Ordered Probit Analysis. World Journal of Agricultural Sciences 3: 543-546

Dogbe W, Etwire PM, Martey E, Etwire JC, Baba IIY, Siise A (2013) Economics of Soybean Production: Evidence from Saboba and Chereponi Districts of Northern Region of Ghana. Journal of Agricultural Research 5: 1-12

Dedehouanou H, Kpanou BV, Koura I, Bakary S, Houndonougbo F, Houngnandan P (2014) Performance des Systèmes Intégrant Agriculture et Elevage (SIAE) endogènes au Bénin. Bulletin de la Recherche Agronomique du Bénin (BRAB) Numéro spécial Economie et Sociologie Rurales Décembre 2014 1-10

DPP/MAEP (2014) Evolution des réalisations des principales cultures par commune (Période: 2004-2013). Cotonou, Bénin.

Ebong VO, Okoro US, Effiong EO (2011) Determinants of Technical Efficiency of Urban Farming in Uyo Metropolis of Akwa Ibom State. Journal of Agriculture and Social Science 5:89-92

Eze CC, Ibekwe UC, Mwajiuba PO (2006). Determinants of adoption of improved production technologies among farmer in Enugu state of Nigeria. Global Approaches Extension Practices 2: 37-44.

Ezeh CI, Anyiro CO, Chukwu JA (2012) Technical Efficiency in Poultry Broiler Production in Umuahia Capital Territory of Abia State, Nigeria. Greener Journal of Agricultural Sciences 2: $1-7$

Houngnandan P, Zapata F, Boeckx P, Van Cleemput O (2009) Effect of Bradyrhizobium inoculation and $\mathrm{N}$ fertilization on promiscuous soybean and subsequent maize yield grown in degraded "Terre de barre" in Benin. Annales des sciences agronomiques 12 : 99-116. doi: 10.4314/asab.v12i2.53855. 
Javaheri F, Baudouin JP (2001) Le soja. In: Raemaerkers RH (Ed). Agriculture en Afrique Tropicale, General Directorate for International Cooperation, Ministry of Foreign Affairs, External Trade and International Cooperation, Brussels, Belgium.

Kabuli A, Phiri MAR, Abdi Khalil E (2005) Economic assessment of the benefits of soybeans incorporation in smallholder maize-based farming systems and the factors affecting its adoption in Malawi. African Crop Science Conference Proceedings 7: 881-885

Koskei RC, Langat JK, Koskei EC, Oyugi MA (2013) Determinants of Agricultural Information Access by Small Holder Tea Farmers in Bureti District, Kenya. Asian Journal of Agricultural Sciences 5: 102-107

Liu XB, Herbert SJ, Zhang QY, Hashemi AM (2006) YieldDensity Relation of Glyphosate-Resistant Soya beans and their Responses to Light Enrichment in North-eastern USA. Journal of Agronomy and Crop Science, 193: 55-62. doi: 10.1111/j.1439-037X.2006.00241.x

Liu X, Jin J, Wang G, Herbert SJ (2008) Soybean yield physiology and development of high-yielding practices in Northeast China. Field Crops Research 105: 157-171. doi:10.1016/j.fcr.2007.09.003.

Mafongoya PL, Mpepereki S, Mudyazhezha S (2009) The importance of biological nitrogen fixation in plants. In Emerich DW, Krishnan HB (Eds). Nitrogen fixation in crop production, American Society of Agronomy, Madison.

Ofuoku AN, Emah GN, Itedjere BE (2008). Information utilization among rural fish farmers in central agricultural zone of Delta State, Nigeria. World Journal of Agricultural Sciences 4: 558-564.

Ohyama T, Ohtake N, Sueyoshi K, Tewari K, Takahashi Y, Ito S, Nishiwaki T, Nagumo Y, Ishii S, Sato T (2009) Nitrogen fixation and metabolism in soybean plants. Nova Science Publishers, Inc. New York

Omobolanle OL (2007) Socio- economic conditions of peasant farmers: the case of agricultural technologies' sustainability in southwest Nigeria. African Journal of Agricultural Research 2: 441-446.

Otitoju MA, Arene CJ (2010) Constraints and determinants of technical efficiency in medium-scale soybean production in benue state, nigeria. African Journal of Agricultural Research 5: 2276-2280.

Raghuvanshi RS, Bisht K (2010) Uses of Soybean: Products and Preparation. In: Singh G (Ed). The Soybean: Botany, Production and Uses, CAB International, USA, pp: 345-374.

Saïdou A, Tossou RC, Kossou D, Sambieni S, Richards P Kuyper TW (2007) Land tenure and sustainable soil fertility management in central Benin: towards the establishment of a cooperation space among stakeholders. International Journal of Agricultural Sustainability 5: 195-212. doi: 10.1080/14735903.2007.9684822

Si W, Wang X (2011) Productivity growth, technical efficiency, and technical change in China's soybean production. African Journal of Agricultural Research 6: 56065613. doi: 10.5897/AJAR11.1080.

Singh G, Hari R, Aggarwal N (2010) Agro-techniques for Soybean Production. In: Singh G (Ed). The Soybean: Botany, Production and Uses, CAB International, USA, pp: 345-374.

Smaling EMA, Roscoe R, Lesschen JP, Bouwman AF, Comunello E (2008) From forest to waste: Assessment of the Brazilian soybean chain, using nitrogen as a marker. Agriculture, Ecosystems and Environment 128: 185-197. doi:10.1016/j.agee.2008.06.005.

Tairo EV, Ndakidemi PA (2014) Macronutrients Uptake in Soybean as Affected by Bradyrhizobium japonicum Inoculation and Phosphorus (P) Supplements. American Journal of Plant Science 5: 488-496. http://dx.doi.org/10.4236/ajps.2014.54063

Wilson RF (2008) Soybean: Market Driven Research Needs. In Stacey G (Ed). Genetics and Genomics of Soybean, Springer Science, New York. doi: 10.1007/978-0-387-72299-3_1. 